\title{
6.3 Diversity of Psychrophilic Bacteria from Sea Ice - and Glacial Ice Communities
}

\author{
Karen Junge ${ }^{1}$ Brent Christner ${ }^{2}$. James T. Staley ${ }^{1}$ \\ ${ }^{1}$ University of Washington, Seattle, WA, USA \\ ${ }^{2}$ Louisiana State University, Baton Rouge, LA, USA
}

Introduction

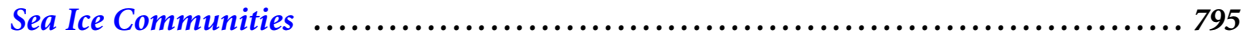

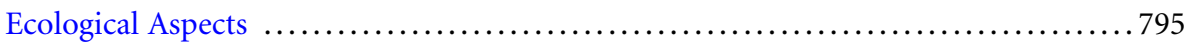

Phylogenetic Diversity of Psychrophilic Sea Ice Bacteria $\ldots \ldots \ldots \ldots \ldots \ldots \ldots \ldots \ldots . \ldots 797$

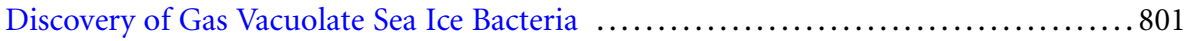

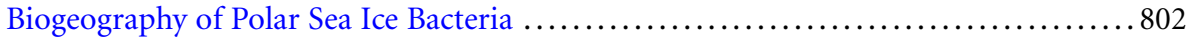

Are Sea Ice Bacteria "Good" Psychrophiles? ................................ 803

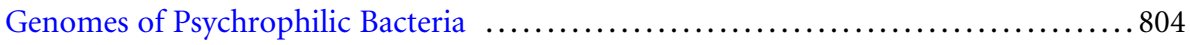

Glacial Ice Microbiology ............................................... 805

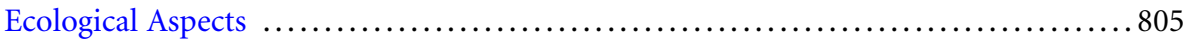

Diversity of Microbial Species Immured in Glacial Ice ........................ 806

Glacial Ice: Archive or Habitat? ......................................... 808

Limits to Longevity in Glacial Ice .................................. 808

Conclusions ............................................................ 810

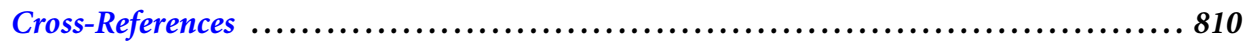




\section{Introduction}

Earth is primarily a cold, marine planet with $90 \%$ of the ocean's waters being at $5^{\circ} \mathrm{C}$ or lower. Frozen soils (permafrost), glaciers and ice sheets, polar sea ice, and snow cover make up $20 \%$ of the Earth's surface environments (Deming and Eicken 2007). A great diversity of microorganisms has been found in these habitats. However, only those that are adapted to life in the cold can be active in them and thus influence biogeochemical cycles.

Cold-adapted microbes are termed psychrophiles or cold-loving, having minimum, optimum and maximum growth temperatures at or below $0^{\circ} \mathrm{C}, 15^{\circ} \mathrm{C}$, and $20^{\circ} \mathrm{C}$, respectively or psychrotolerant (with growth maxima above $25^{\circ} \mathrm{C}$ but the capacity to grow to very low temperature (Morita 1975). Recently, additional definitions have been proposed, such as "moderate psychrophiles" with a minimum and maximum growth temperature at or below $0^{\circ} \mathrm{C}$ and $25^{\circ} \mathrm{C}$ (Helmke and Weyland 2004), "psychro-active" (organisms growing at or below $-1^{\circ} \mathrm{C}$, Laucks et al. 2005) and the terms "eurypsychrophile" and "stenopsychrophile" have been suggested (Caviocchiolli 2006 and references therein). Stenopsychrophile (formerly "true psychrophile") refers to a microorganism with a restricted growth-temperature range that cannot tolerate higher temperatures for growth. Eurypsychrophile (the formerly "psychrotolerant" or "psychrotroph") describes a microorganism that prefers permanently cold environments, but can also tolerate a wide range of temperatures reaching up into the mesophilic range (Caviociolli 2006). In this review we use the term psychrophile as a general term to describe a microorganism that grows in a cold environment. Specifically, we focus in this review on the diversity of psychrophiles found in the two major marine and terrestrial cold habitats for life on Earth - sea ice and glacier ice.

Marine psychrophiles play a globally significant role in biogeochemical cycling (Helmke and Weyland 2004). In the polar regions, they are important as processors of polar marine primary productivity (Legendre et al. 1992), which serves as the base for the entire polar food web, ultimately feeding krill, fish, whales, penguins, and seabirds. The rate of primary production varies greatly throughout Arctic and Antarctic marine waters and ice, and underlying environmental factors important to this process are investigated (Mock and Thomas 2005; Garneau et al. 2009; Kellogg and Deming 2009; Arrigo et al. 2010). Psychrophilic bacteria are of interest not only because they play important roles in organic carbon and elemental transformations throughout the polar food web (terrestrial and aquatic), but also because of their remarkable ability to thrive under extremely cold and salty conditions (Thomas and Dieckmann 2002). The enzymes and membranes that enable psychrophiles to live at low temperatures are of considerable interest for biotechnological and industrial applications (see $>$ Chap. 6.7 Psychrophilic Enzymes: Cool Responses to Chilly Problems).

Cold environments on Earth are extremely sensitive to global warming, especially those in the polar regions. As a result of increasing temperatures, the livelihood of larger organisms that perform critical ecological roles in the food chains of these cold environments (such as Polar Bears) is threatened. How microorganisms that also perform critical ecological roles might respond to these changes is an important and urgent question that requires attention (Kirchman et al. 2009). Furthermore, cold temperatures are prevalent in extraterrestrial environments, and especially in most outer planets and moons in our solar system. Therefore, from an astrobiological perspective, studying frigid environments on Earth can provide important clues and technology for understanding life that may exist elsewhere in our solar system, such as on Mars and Jupiter's moon, Europa. 
In the following sections, we present what is known to date about the diversity of cultured and uncultured psychrophilic bacteria in sea ice and glacial ice and describe their habitats. We furthermore discuss briefly the adaptive strategies in Psychrobacter ingrahamii, a "true" psychrophile (i.e., stenopsychrophile) and discuss processes that could lead to extended longevity of microbes immured in glacial ice.

\section{Sea Ice Communities}

\section{Ecological Aspects}

One needs to appreciate the physics and chemistry of sea ice in order to understand the ecology and adaptation mechanisms of the bacteria that live within. Sea ice is one of the largest habitats in polar oceans and plays a crucial role in structuring the whole polar ecosystem (Eicken 1992). At its maximum extent, the ice covers $13 \%$ of the Earth surface with the largest expanse occurring in the Southern ocean where, during the winter months, 20 million square kilometers are covered by ice. In recent years, Arctic sea ice has shown a dramatic decrease in thickness and extent due to increasing overall temperatures in Arctic regions caused by global change (Stroeve et al. 2005; Serreze et al. 2007).

Seawater which typically contains about $34 \mathrm{~g}$ of dissolved salts and ions (mostly sodium, chloride, sulfate, magnesium, calcium and potassium) begins to freeze when temperatures drop below $-1.86^{\circ} \mathrm{C}$. Ice crystals begin to form and rise to the surface. These initial crystals (called frazil ice) are of varying shape, from plates to needles; and size, from $\leq 1.0 \mathrm{~mm}$ to $1.0 \mathrm{~cm}$ in length (Mock and Junge 2007 and references therein; also see Petrich and Eicken 2010 for an in-depth review on ice development, its micro and macrostructure).

Within hours, frazil ice crystals consolidate by wind and water motion to form loosely aggregated disks (called pancakes). After a few days of growth by accumulation of more and more ice crystals that form in the upper water column, pancakes can be several meters across and up to $50 \mathrm{~cm}$ thick. They freeze together forming a closed ice cover after 1-2 days (termed pack ice). As temperatures continue to decrease this pack ice thickens, not necessarily by the accumulation of more ice crystals, but by the growth of columnar ice at the ice-water interface. Columnar ice forms by the vertical elongation of frazil ice crystals. The proportion of frazil ice to columnar ice depends largely on the turbulence of the water in which it was formed. The more turbulent the water, the more frazil ice is usually found. Antarctic sea ice contains up to $80 \%$ frazil ice as it is formed under more turbulent conditions. In the Arctic, sea ice is formed under more calm conditions and contains up to $80 \%$ columnar ice. This difference is important for sea ice biology because frazil ice provides more habitable space for organisms than columnar ice (Spindler 1990).

When ice is formed from seawater, dissolved salts, air and other "impurities" in the seawater, including bacteria, inorganic and organic dissolved and particulate matter, are not incorporated into the freshwater ice crystals and instead are concentrated into a salty brine that persists as inclusions of pockets and channels within the ice or is released into the water below (Eicken 1992). These channels vary in size from a few micrometeres to several millimeters in diameter and represent the main habitat for all sea ice microorganisms ( $\odot$ Fig. 6.3.1, Mock and Junge 2007). 

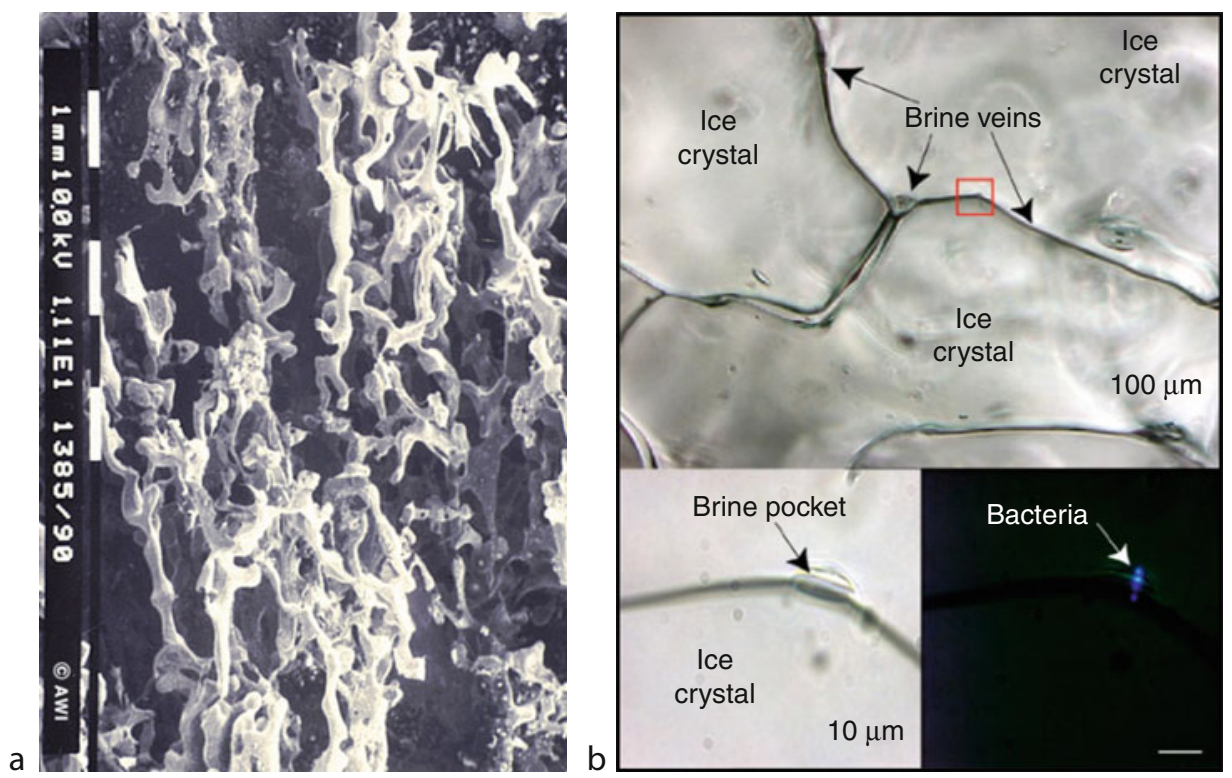

Fig. 6.3.1

(a) SEM picture of the brine channels system in columnar sea ice made visible by filling the system with epoxy resin under a vacuum. Picture by Alfred-Wegener Institute for Polar and Marine Research, Bremerhaven, Germany (Junge and Mock 2007, reprinted with permission from Springer Verlag). (b) In situ microscopic images of (a) ice crystals and brine pockets and (b) detail of a brine pocket in (a) that harbors bacteria stained with the blue DNA stain DAPI (Adapted from Junge et al. 2001)

Temperature determines the volume of brine channels and the concentration of salts within them; with decreasing temperatures, brine volumes decrease and salt content (salinity) increases. Thus, the coldest ice contains brine channels with the saltiest brines, and overall fewer, smaller and less interconnected channels than warmer ice. Ice at the sea ice-air interface is usually colder than ice in contact with the underlying water resulting in vertical temperature(salinity and brine volume) gradients throughout the ice ( Fig. 6.3.2). The ice is considered permeable at temperatures above $-5^{\circ} \mathrm{C}$ (with corresponding bulk melt salinities of $5 \%$ o in situ salinities of $90 \%$ ] and brine volume fractions above $5 \%$ ). Below $-5^{\circ} \mathrm{C}$ sea ice is effectively impermeable with no convective fluid flow occurring (Golden et al. 1998).

The majority of sea ice is ephemeral, with melting during the summer season releasing the community into the underlying water. Melting forms ponds on the surface of the ice (mostly in the Arctic), which develop their own unique ice-algae assemblages and microbial communities (Brinkmeyer et al. 2004). When melting continues due to increasing water temperatures and solar irradiance on top of the ice, the ice gets thinner and more porous, and the majority melts completely. If ice survives the summer, refreezing occurs during the following winter that makes the ice even thicker. The longevity of the ice depends on the geographic location, wind and ocean currents. Sea ice of northern Greenland and the Canadian archipelago can be several years old with an average thickness of 6-8 $\mathrm{m}$. The ice in the Southern Ocean is considerably 


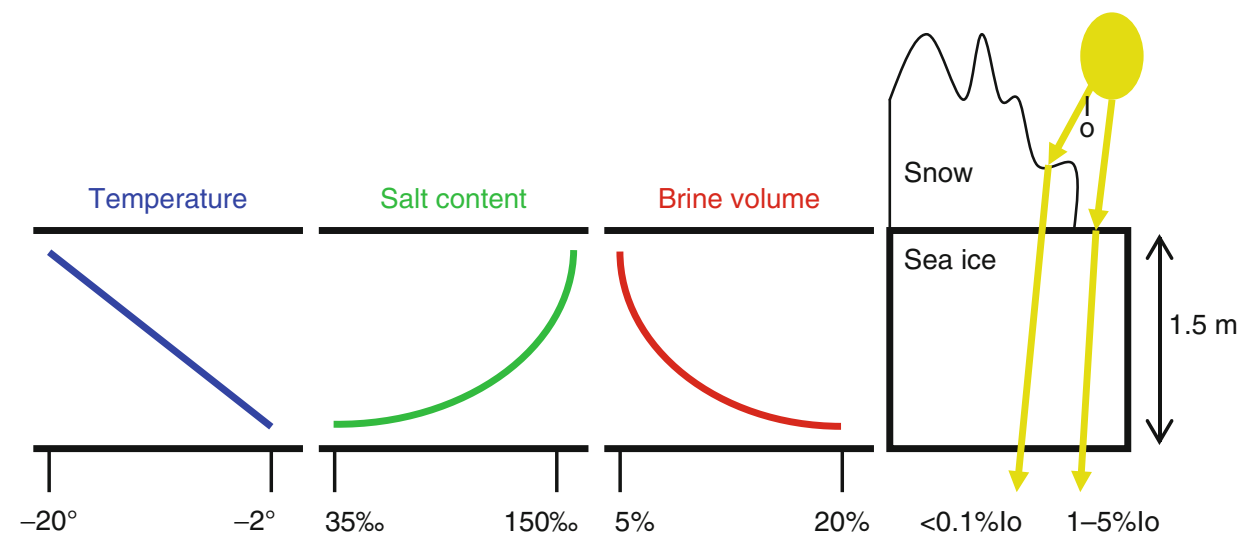

Fig. 6.3.2

Vertical gradients of temperature, salt content, brine volume and irradiance through sea ice. These general patterns may vary due to changes in temperature (Adapted from Mock and Junge 2007)

thinner with an average thickness of only $1 \mathrm{~m}$. Such differences in physical properties of the ice also result in differences in the abundance, activity and composition of the microbial communities within (Mock and Junge 2007).

Psychrophilic bacteria that grow in sea ice must be adapted to cope with these everchanging physical and chemical conditions of their environment after they are introduced into the ice as it forms. Along with salts, other dissolved impurities and particulate material, the cells are excluded from the newly formed ice crystals and reside in the brine channels (Junge et al. 2001). However, they may also become incorporated into the ice when attached to algae that adhere to ice crystals when they rise through the water as it freezes in autumn (Ackley and Sullivan 1994).

In the following sections we review the state of knowledge on the phylogenetic diversity of psychrophilic sea ice bacteria both from cultivation studies and whole community analyses. A discussion on the discovery of gas-vacuolate sea ice bacteria and the biogeography of sea ice bacteria follows. We end with a brief description of Psychrobacter ingrahamii as a representative of the stenopsychrophilic sea ice bacteria.

\section{Phylogenetic Diversity of Psychrophilic Sea Ice Bacteria}

Annually during spring and summer, extensive microbial communities (termed SIMCO for sea ice microbial community) develop within sea ice (for recent reviews see Mock and Thomas 2005, Mock and Junge 2007, Deming 2009). The SIMCO are usually dominated by ice-algae assemblages composed primarily of pennate diatoms (reviewed by Mock and Junge 2007). The populations within the ice are often so rich that the ice appears brown-green to the naked eye. Heterotrophic bacteria represent another major group within these communities (as are viruses; recently reviewed by Deming 2010), as evidenced by (1) measures of bacterial abundance, activity and production, (2) the microbial loop and (3) phylogenetically diverse 
bacterial assemblages. Heterotrophic protozoa, amphipods, invertebrate larvae, copepods, euphausids such as krill, nematodes, turbellarians and some fishes are the larger protozoan and metazoan consumers found in sea ice (for reviews on these larger consumers see various chapters in Thomas and Dieckman 2010).

Over the last 2 decades, the phylogenetic diversity of sea ice bacteria has been studied extensively, mostly during spring and summer (e.g., Gosink and Staley 1993; Bowman et al. 1997; Brown and Bowman 2001; Junge et al. 2002, Brinkmayer et al. 2003) and more recently during winter as well (e.g., Brinkmayer et al. 2003; Junge et al. 2004; Collins et al. 2010). Efforts have mainly focused on polar Arctic and Antarctic sea ice, with some research performed in other sea ice-influenced water bodies such as the Baltic Sea (e.g., Petri and Imhoff 2001; Kaartokallio et al. 2008), Okhotsk Sea and Sea of Japan (Romanenko et al. 2008). Culturing efforts both in the Antarctic and Arctic have yielded new genera and species within the divisions of the Proteobacteria phylum including the Alphaproteobacteria, Betaproteobacteria and the Gammaproteobacteria classes, the Bacteriodetes phylum (formerly called

Table 6.3.1

Psychrophilic phyla, genera and species described from sea ice, with their temperature optima or range for growth (list amended from data compiled by Bowman J, personal communication and Deming 2010). Genera only represented by environmental sequences are in bold, genera only known from melt ponds and Baltic Sea ice are indicated by $(\mathrm{mp})$ and (bs), respectively

\begin{tabular}{|c|c|c|c|}
\hline $\begin{array}{l}\text { Phyla and associated } \\
\text { genera }\end{array}$ & Species & $\begin{array}{l}\mathrm{T}_{\text {opt }} \text { or } \mathrm{T}_{\text {range }} \text { for } \\
\text { growth }\left({ }^{\circ} \mathrm{C}\right)\end{array}$ & Reference(s) \\
\hline \multicolumn{4}{|l|}{ Bacteria } \\
\hline \multicolumn{4}{|l|}{$\gamma$-proteobacteria: } \\
\hline Acinetobacter & Colwellia psychrerythraea & $9-16$ & $\begin{array}{l}\text { D'Aoust and Kushner } \\
\text { (1972), Bowman et al. } \\
\text { (1998a), Huston et al. } \\
(2000)\end{array}$ \\
\hline Alteromonas & Colwellia demingiae & $10-15$ & Bowman et al. (1998a) \\
\hline Citrobacter & Colwellia hornerae & 10 & Bowman et al. (1998) \\
\hline Colwellia & Colwellia rossensis & 10 & Bowman et al. (1998a) \\
\hline Glacieocola & Glaciecola pallidula & $13-14$ & Bowman et al. (1998b) \\
\hline Halomonas & Glaciecola punicea & $15-18$ & Bowman et al. (1998b) \\
\hline Iceobacter & Psychrobacter glacincola & $15-21$ & Bowman et al. (1998d) \\
\hline Marinobacter & Psychromonas boydii & $0-10$ & Auman et al. (2009) \\
\hline Marinomonas & Psychromonas ingrahamii & -12 to 10 & Auman et al. (2006) \\
\hline Neptunomonas & Shewanella gelidimarina & 16 & Bowman et al. (1997b) \\
\hline Oceanospirillum & Shewanella frigidimarina & 20 & Bowman et al. (1997b) \\
\hline \multicolumn{4}{|l|}{ Pseudoalteromonas } \\
\hline \multicolumn{4}{|l|}{ Pseudomonas } \\
\hline \multicolumn{4}{|l|}{ Psychrobacter } \\
\hline Shewanella & & & \\
\hline
\end{tabular}


Table 6.3.1 (Continued)

\begin{tabular}{|c|c|c|c|}
\hline $\begin{array}{l}\text { Phyla and associated } \\
\text { genera }\end{array}$ & Species & $\begin{array}{l}\mathrm{T}_{\text {opt }} \text { or } \mathrm{T}_{\text {range }} \text { for } \\
\text { growth }\left({ }^{\circ} \mathrm{C}\right)\end{array}$ & Reference(s) \\
\hline \multicolumn{4}{|l|}{ Terridinibacter } \\
\hline \multicolumn{4}{|l|}{ Vibrio } \\
\hline \multicolumn{4}{|l|}{ 及-proteobacteria: } \\
\hline Aquaspirillum (mp) & Polaromonas vacuolatus & 10 & Irgens et al. (1996) \\
\hline \multicolumn{4}{|l|}{ Matsuebacter (mp) } \\
\hline \multicolumn{4}{|l|}{ Rhodoferaz (mp) } \\
\hline \multicolumn{4}{|c|}{ Ultramicrobacterium (mp) } \\
\hline \multicolumn{4}{|l|}{ Comamonadaceae (bs) } \\
\hline \multicolumn{4}{|l|}{ Hydrogenophaga (bs) } \\
\hline \multicolumn{4}{|l|}{$\alpha$-proteobacteria: } \\
\hline Octadecabacter & Octadecabacter arcticus & 10 & Gosink et al. (1997) \\
\hline Roseobacter & $\begin{array}{l}\text { Octadecabacter } \\
\text { antarcticus }\end{array}$ & 8 & Gosink et al. (1997) \\
\hline \multicolumn{4}{|l|}{ Ruegeria } \\
\hline \multicolumn{4}{|l|}{ Sphingomonas } \\
\hline \multicolumn{4}{|l|}{ Sulfitobacter } \\
\hline \multicolumn{4}{|l|}{ Devosia (mp) } \\
\hline \multicolumn{4}{|l|}{ Rhodobacter (mp) } \\
\hline \multicolumn{4}{|l|}{ Loktanella (bs) } \\
\hline \multicolumn{4}{|c|}{ Bacteroidetes (former CFB): } \\
\hline Cellulophaga & Flavobacterium gillisiae & 20 & $\begin{array}{l}\text { McCammon and } \\
\text { Bowman (2000) }\end{array}$ \\
\hline Cytophaga & Gelidibacter algens & $15-18$ & Bowman et al. (1997c) \\
\hline Cyclobacterium (mp) & Polaribacter irgensii & $8-10$ & Gosink et al. (1998) \\
\hline Flavobacterium & Polaribacter franzmannii & 7 & Gosink et al. (1998) \\
\hline Flexibacteraceae (bs) & Polaribacter filamentus & $10-12$ & Gosink et al. (1998) \\
\hline Gelidibacter & Psychroflexus torquis & 12 & Bowman et al. (1998c) \\
\hline \multicolumn{4}{|l|}{ Hymenobacter (mp) } \\
\hline \multicolumn{4}{|l|}{ Lewinella } \\
\hline \multicolumn{4}{|l|}{ Salegentibacter } \\
\hline \multicolumn{4}{|l|}{ Polaribacter } \\
\hline \multicolumn{4}{|l|}{ Psychroflexus } \\
\hline \multicolumn{4}{|l|}{ Psychroserpens } \\
\hline \multicolumn{4}{|c|}{ Green non-sulfur bacteria } \\
\hline \multicolumn{4}{|l|}{ Planctomycetes } \\
\hline \multicolumn{4}{|l|}{ Planctomycetales $(\mathrm{mp})$} \\
\hline \multicolumn{4}{|l|}{ Verrucomicrobia } \\
\hline \multicolumn{4}{|l|}{ Verrucomicrobium } \\
\hline Prosthecobacter & & & \\
\hline
\end{tabular}


Table 6.3.1 (Continued)

\begin{tabular}{|c|c|c|c|}
\hline $\begin{array}{l}\text { Phyla and associated } \\
\text { genera }\end{array}$ & Species & $\begin{array}{l}T_{\text {opt }} \text { or } T_{\text {range }} \text { for } \\
\text { growth }\left({ }^{\circ} \mathrm{C}\right)\end{array}$ & Reference(s) \\
\hline \multicolumn{4}{|c|}{ Purple sulfur bacteria (bs) } \\
\hline \multicolumn{4}{|l|}{ Firmicutes: } \\
\hline Halobacillus & $\begin{array}{l}\text { Planomicrobium } \\
\text { mcmeekinii }\end{array}$ & $0-37$ & $\begin{array}{l}\text { Junge et al. (1998), Yoon } \\
\text { et al. (2001) }\end{array}$ \\
\hline \multicolumn{4}{|l|}{ Planomicrobium } \\
\hline \multicolumn{4}{|l|}{ Actinobacteria: } \\
\hline Corynebacterium & Arthrobacter & $0-30$ & Junge et al. (1998) \\
\hline Clavibacter & Brachybacterium & $0-30$ & Junge et al. (1998) \\
\hline $\begin{array}{l}\text { ARCHAEA (only from } \\
\text { winter ice) }\end{array}$ & & & Collins et al. (2010) \\
\hline \multicolumn{4}{|l|}{ Crenarchaeota } \\
\hline \multicolumn{4}{|l|}{ Marine Group I } \\
\hline \multicolumn{4}{|l|}{ Euryarchaeota } \\
\hline Group IIb & & & \\
\hline
\end{tabular}

the Cytophaga-Flexibacter-Bacteroides or CFB phylum) and the Actinobacteria phylum (see $>$ Table 6.3.1 for a list of psychrophilic sea ice bacterial isolates described to date and associated references). Many of the described Arctic and Antarctic sea ice bacteria are stenopsychrophiles with growth optima or maxima below $15^{\circ} \mathrm{C}$. Most bacteria isolated from sea ice have been observed to be pigmented, highly cold-adapted with some able to form gas vesicles (see below and Sullivan and Palmisano 1994; Grossi et al. 1984; Staley et al. 1989; Gosink and Staley 1995).

Sea ice bacteria have been found to be unusually easy to cultivate - with up to $60 \%$ of the total bacterial population being culturable (Junge et al. 2002; Brinkmayer et al. 2003). This stands in marked contrast to the culturability of most seawater bacteria $(\sim 0.01 \%$ of the total cell count, Amann et al. 1995) and might be due to the exceptionally high concentrations of labile dissolved organic matter (DOM) released by ice algae reported for sea ice brines in the Arctic, Antarctic and Baltic Sea (to exceed surface water concentration by factors of up to 500; Thomas and Mock 2005 and references therein). This likely explains why sea ice bacteria are so readily cultivated both in low and high nutrient media (Junge et al. 2002) and why groups commonly associated with marine algae are repeatedly found in sea ice bacterial culture collections.

Small subunit rRNA gene sequence analyses of whole communities have demonstrated an unexpectedly strong congruence with cultivation data. Mostly, the same phyla and genera were found to be present (Brown and Bowman 2001; Brinkmayer et al. 2003), except for a few clones grouping among the Verrucomicrobia, closest to the prosthecate aerobic genera Verrucomicrobium and Prosthecobacter (Brown and Bowman 2001). No evidence of uncultured bacterial clone groups such as SAR11, SAR86 or archaeal groups that commonly occur in oceanic non-polar and polar seawater samples had been found in the Arctic and Antarctic spring/summer ice or melt ponds studied (Brinkmeyer et al. 2004). 
Molecular and cultivation studies on Arctic summer time ice-melt ponds revealed another group that had not been found previously in the interior of the ice. $\beta$-Proteobacterial genera known only from freshwater habitats were found to dominate in the mostly freshwater ponds (along with gram-positives species, $\alpha$ - and $\gamma$-Proteobacterial genera occurring in more saline ponds and Bacteriodetes members in sediment containing ponds; Brinkmeyer et al. 2004).

Anaerobic phototrophic purple sulpfur bacteria have also been found in the interior of Baltic sea ice (Petri and Imhoff 2001), indicating that oxygen deficient and anoxic zones are present in sea ice. High amounts of mucopolysaccharide gels and exopolymeric substances (EPS) are suggested to provide oxygen-depleted microhabitats for these species within the sea ice habitat (Mock and Thomas 2005). Other Baltic sea ice studies showed denitrification to occur in zones of ice with accumulated nitrite (Kaartokallio 2001). In Arctic sea ice, anaerobic bacterial denitrification with high numbers of anaerobic nitrate reducing bacteria and ammonium oxidation was found in zones with high levels of nitrate, ammonium ions and DOM (Rysgaard and Glud 2004; Rysgaard et al. 2008), which are characteristics of many sea ice habitats (reviewed by Thomas and Dieckmann 2002).

Archaea were found in low numbers (up to $4 \%$ of the population) in Arctic wintertime sea ice samples (Junge et al. 2004) but not in any of the Spring- and Summer time Arctic and Antarctic ice samples cited above. More recently, the presence of Archaea in winter time sea ice was confirmed during a seasonal study of community composition over the course of the Arctic winter (Collins et al. 2010). Surprisingly it was also found that communities of Bacteria and Archaea in the ice resembled that in the underlying water. The microbial community consisted primarily of SAR-11 clade alpha Proteobacteria and Marine Group 1 Crenarcheaota, neither of which is known from Spring and Summer time sea ice. The wintertime ice bacterial clone library contained $\gamma$-proteobacteria from oligotrophic seawater clades (e.g., OM60, OM182) and no clones from $\gamma$-proteobacteria genera commonly detected in spring and summertime ice (e.g., Colwellia, Psychrobacter) were observed. It was concluded that selection during ice formation and mortality during winter played minor roles in the process of microbial succession that leads to distinctive spring and summer sea ice bacterial communities (Collins et al. 2010). Seasonal studies that explore the winter/spring/summer transitions are needed to explore further how distinctive summer and spring time communities develop but factors such as extensive algal growth resulting in increased highly labile DOM levels are likely determining factors.

\section{Discovery of Gas Vacuolate Sea Ice Bacteria}

Gas vesicles, which have been hypothesized to be an early organelle of prokaryotic motility (Staley 1980), are intracellular structures found in many aquatic Bacteria and Archaea (Walsby 1994). They appear as bright areas in cells that contain them when they are observed by light microscopy. To distinguish them from other bright, intracellular areas in cells, they need to be visualized by transmission electron microscopy. Each gas vacuole observed by TEM contains many subunits that are termed gas vesicles. The membranes of the gas vesicles consist of a hydrophobic protein with a molecular weight of about 7,500, which is the subunit of the gas vesicle. The subunits are arrayed in a manner that produces a central cylindrical structure capped at each end by conical tips.

The function of the gas vesicles is that they to provide buoyancy to the organism. This is accomplished by excluding water into the interior of the vesicles because of the hydrophobic 
vesicle membrane. However, gases are freely permeable through the vesicle membranes so that gases in the ambient environment accumulate in the interior of the vesicle. As a result, the vesicles decrease the density of the cells thereby providing buoyancy.

Gas vacuolated bacteria are very common in freshwater habitats, especially those that have a thermally stratified water column. Typically in these habitats the gas vacuolated cyanobacteria that produce blooms in lakes are found in the surface waters where they receive abundant light for photosynthesis. In the deeper hypolimnion of stratified lakes, blooms of anoxygenic photosynthetic bacteria, many of which contain gas vacuoles, occur. Gas vacuolated bacteria and archaea are also found in the hypolimnion and even in freshwater sediments.

In 1989, marine gas vacuolate bacteria were reported from euphotic waters off the Palmer Peninsula (Irgens et al. 1989). Based on this discovery, it was hypothesized that gas vacuolate bacteria, which are typically found in stratified aquatic habitats might be indigenous to the SIMCO because it is a dramatic example of a stratified marine habitat in which underlying cold water is capped by the SIMCO ice layer.

To test this hypothesis, more intensive studies were performed at McMurdo Sound, where the sea ice community is more amenable to study. Sure enough, gas vacuolate bacteria were encountered, in some instances at very high concentrations relative to total cultivable bacteria, in the SIMCO layer, underlying frazil ice layer and water column (Staley et al 1989). It is still not known whether the gas vesicles are expressed when they are in the SIMCO layer but it is thought that they are likely expressed after the summer thaw when the sea ice microbial community is dispersed in the water column. The evidence for this is that the gas vacuolated strains were only isolated from samples taken from the surface waters and to depths down to $50 \mathrm{~m}$ whereas none were isolated from lower depths, i.e., 100, 200, and $500 \mathrm{~m}$.

The taxonomy of the gas vacuolated bacteria followed their isolation. The first described gas vacuolated bacterium from Antarctica, Polaromonas vacuolata, is a member of the Proteobacteria (Irgens et al. 1996). Although Polaromonas vacuolata, is likely a member of the SIMCO, this bacterium was isolated from open waters during the summer months so its association with the SIMCO is uncertain. However, many gas vacuolated bacteria have been isolated from the SIMCO layer and identified.

The gas vacuolate bacteria isolated and described taxonomically from sea ice fall into two major phylogenetic groups, the phyla, Proteobacteria and Bacteroidetes (Staley et al 1989; Gosink and Staley 1995). Examples of gas-vacuolate sea ice bacteria that have been named belong to Proteobacterial genera, Octadecabacter (Gosink et al. 1997), Psychromonas (Auman et al. 2006; Auman et al. 2009) and the Bacteroidetes genus Polaribacter (Gosink et al. 1998).

\section{Biogeography of Polar Sea Ice Bacteria}

One of the reasons for studying the bi-polar distribution of sea ice bacteria, is to evaluate whether the same species are found at each pole. Baas-Becking's hypothesis (1934) that "everything is everywhere, the environment selects" indicates that polar sea ice bacteria should be cosmopolitan. Therefore, the two polar environments should contain the same species of bacteria. Staley has hypothesized that this is improbable and therefore psychrophilic bacteria from each pole should be endemic, separate species (Staley, ASM News; Staley and Gosink 1999). He reasoned that the great distances between the two poles and the difficulty of dispersing stenopsychrophiles, which quickly die at room temperature, across tropical areas through various means, such as animal vectors like the arctic tern or long transport via deep 
ocean circulation under deep sea pressures, might make it improbable that the same species would be found at each pole.

To test this hypothesis, a number of strains of unique psychrophilic gas vacuolated bacteria were isolated from each pole and compared. The closest matches that were found were strains were from the genera Octadecobacter and Polaribacter. This indicates, that at the level of the genus, these bacteria are cosmopolitan in their distribution.

The 16S rRNA gene sequences of the two most closely related strains of Octadecobacter isolated from the two poles, were $<1 \%$. Therefore, in order to determine whether they were separate species, DNA-DNA hybridization was performed. The reassociation value at $42 \%$ was well below the $>70 \%$ required for them to be the same species. Therefore the new species were named O. arcticus and O. antarcticus to reflect the two different poles from which they were isolated (Gosink et al. 1997).

Likewise, four Polaribacter strains isolated from the two separate poles were also compared. The two most closely related strains based on DNA-DNA hybridization showed $34 \%$ relatedness, again significantly lower than the $70 \%$ required for them to be the same species (Gosink et al. 1998). Each strain was therefore named as a separate species of the genus.

Junge et al. (2002) reported on an Arctic isolate (Shewanella frigidimarina) which showed $100 \%$ sequence similarity to a Shewanella frigidimarina isolate from Antarctica, suggesting bipolar distribution for bacteria even at the species level and thus possibly reversing the earlier suggestion of endemism by Staley and Gosink (1999). However, DNA-DNA hybridization tests are needed to confirm this suggestion. Furthermore, despite the implication of its species name, frigidimarina, the type species of Shewanella frigidimarina is not a stenopsychrophile because its maximum temperature for growth is $30^{\circ} \mathrm{C}$. In contrast the gas vacuolated sea ice bacteria tested for bipolar endemism were true stenopsychrophiles that do not grow above $10-15^{\circ} \mathrm{C}$ and cannot survive at room temperature and are therefore highly unlikely to survive transport across the equator.

Thus to date no definitive evidence of cosmopolitan bi-polar strains of stenopsychrophilic bacteria from the SIMCO habitat has yet been established. Multiple-locus sequence analysis (MLSA) is an alternative approach to resolving this question (Whitaker et al. 2002). This approach would require the isolation and comparison of several closely related strains of a presumed "species" from each pole for a more complete comparative analysis.

\section{Are Sea Ice Bacteria "Good" Psychrophiles?}

Not all organisms that grow in polar environments are steno-psychrophiles. For example, typical bacteria isolated from Antarctic soils may grow in the laboratory at temperatures above $25^{\circ} \mathrm{C}$. This may be due to the large annual fluctuation in temperatures in soils. In contrast, polar marine environments are consistently cold. Temperatures in many areas do not exceed $2^{\circ} \mathrm{C}$ during the year and temperatures in the sea ice are colder. Therefore, in general, the sea ice environment has been an excellent source of psychrophilic bacteria. The question arises, are there features that are typically found in organisms that make them steno-psychrophiles?

Several attributes of bacteria make them good candidates for psychrophily. For example low growth temperatures provide a basis for predicting a psychrophilic life style. It should be noted that low temperature for growth as contrasted with low temperature for metabolism provides a better indicator of psychrophily. As with thermophiles, the maximum temperature for growth is the hallmark of thermophily. Therefore, using the same rationale, the lowest 
temperature for growth should be the maxim for psychrophily. Furthermore, it is very difficult to accurately identify and assess in situ microbial activities in frozen habitats (for advances in this area see Junge et al. 2004 and 2006).

Low maximum growth temperature. One feature is that stenopsychrophiles have a low maximum temperature for growth. Most of the sea ice bacteria do not grow at room temperature and many do not grow at temperatures above $10^{\circ} \mathrm{C}$. This feature is an important predictor for psychrophily, because most bacteria have a limited temperature range for growth. E. coli for example, grows at a low of $8^{\circ} \mathrm{C}$ and at a high of $44^{\circ} \mathrm{C}$. Therefore its temperature range is $36^{\circ} \mathrm{C}$. Likewise, extreme thermophiles, such as species in the genus Pyrococcus, which grow from about $80-110^{\circ} \mathrm{C}$, have a growth temperature range of about $30^{\circ} \mathrm{C}$.

Therefore, if we extrapolate this information to psychrophiles, if they have a maximum growth temperature of $10^{\circ} \mathrm{C}$, they could actually grow at temperatures as low as $-20^{\circ} \mathrm{C}$ or perhaps lower.

Compatible solute production. Another feature of a typical steno psychrophile is its ability to produce an intracellular solute to counterbalance the osmotic effect of higher salinities in brine pockets where organisms reside, that are encountered as sea ice freezes.

Habitat. The lowest temperatures encountered in sea ice occur in the winter month at the air-ice interface. Therefore, it would seem logical that organisms that are located in the upper layers of the sea ice are good candidates for psychrophily.

Low mol\% G+C content. From a purely theoretical standpoint, DNA replication may be aided at low temperatures when there are fewer hydrogen bonds. DNA with a low $\mathrm{G}+\mathrm{C}$ content would have more double-bonded AT nucleotides and fewer GC nucleotides thereby aiding in replication. Consistent with this argument is that several psychrophilic bacteria have mol\% G+C contents below 50\%. It should be noted, however, that some thermophilic bacteria also have mol\% G+C values below 50\%, e.g., in Sulfolobus species it ranges from about 35-42 mol\%, so this pattern may not apply to thermophiles.

A good example for a sea ice bacterial species exhibiting all of the features listed above that are consistent with psychrophilic growth is $P$. ingrahamii. Its maximum growth temperature is $10^{\circ} \mathrm{C}$. Therefore, its minimum growth temperature, in theory could be at least $-20^{\circ} \mathrm{C}$, if we accept the modest estimate of a $30^{\circ} \mathrm{C}$ temperature range for its growth. The lowest growth temperature recorded for this organism is $-12^{\circ} \mathrm{C}$ (Breezee et al. 2008). However, the authors noted that it is likely that the organism can grow at even lower temperatures, but the conditions they used for lower temperatures resulted in freezing the cultures which resulted in cessation of growth.

P. ingrahamii was isolated from the upper half of a sea ice column in Elson lagoon, near Pt. Barrow, Alaska. This lagoon has a slightly higher salinity than typical seawater thereby also providing conditions to lower the freezing point of lagoon's water.

The mol\% G+C of $P$. ingrahamii is 40.1 , lower than that of many other members of the Gammaproteobacteria. Finally, genomic analyses of this organism indicate that it produces a compatible solute, betaine choline aiding its growth under high salinity conditions encountered in brine pockets in the ice (Riley et al. 2008).

\section{Genomes of Psychrophilic Bacteria}

Several genomes of psychrophilic bacteria have been published. They include Colwellia psychroerythraea 34H (Methé et al. 2005), Idiomarina loihiensis L2TR, Pseudoalteromomas 
haloplanktis TAX 125 in addition to Psychromonas ingrahamii (Riley et al. 2008). For further information on this subject we refer the reader to an excellent review of the genomes of psychrophilic bacteria written by Bowman (2008).

\section{Glacial Ice Microbiology}

\section{Ecological Aspects}

The ice sheets of Greenland and Antarctica represent most of the glacial ice on Earth, which cover about $10 \%$ of Earths terrestrial surface and contain $77 \%$ of the freshwater on the planet (Miteva 2008). Temperate, high altitude non-polar glaciers are found all over the world (e.g., China has more than 46,000 glaciers) and represent an important freshwater source for millions of people. Glaciers can range from a few hundred meters to $4 \mathrm{~km}$ in depth, with temperatures increasing with depth (e.g., the glacier overlying Lake Vostok in Antarctica exhibits $-60^{\circ} \mathrm{C}$ to $-2^{\circ} \mathrm{C}$ from surface to base).

The physicochemical characteristics and structure of the polycrystalline glacier ice as a microbial habitat have recently received more attention where it is now understood that cells reside either in liquid filled veins (cells need to be less than $2 \mu \mathrm{m}$; $>$ Fig. 6.3.3; Mader et al. 2006) containing variable substrates suitable to support bacterial metabolism and survival or in the thin liquid films on the surface of mineral grains (see below; Miteva 2008). Furthermore, clear glacier ice and basal ice show significant differences (with basal ice containing much higher concentrations of inorganic and organic ions and minerals) resulting in significant differences in the microbial populations within (with much higher abundances in the latter and a possible function of basal ice microbes in geochemical cycling reactions within the ice,

a
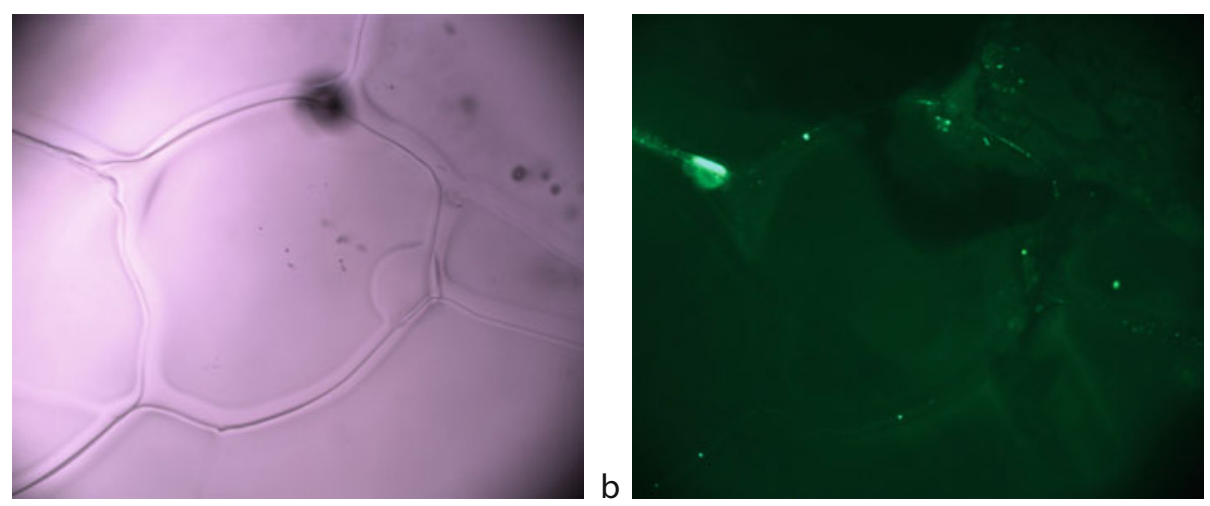

Fig. 6.3.3

Cryostage microscopic image at $-20^{\circ} \mathrm{C}$ of microbial cells within an ice vein habitat. A thin section of glacial ice from the Taylor Glacier (McMurdo Dry Valleys, Antarctica) was mounted on a microscope slide and overlain with a saline solution of SYBR Green I. (a) Bright field image of the ice; (b) the same area under epifluorescence showing DNA-containing cells in the interstitial habitat between ice crystals. Each micrograph is $\sim 1,000 \mathrm{~mm}$ in width. Images: K. Suematsu, visiting researcher, LSU 
see $>$ Chap. 6.5 Ecological Distribution of Microorganisms in Terrestrial, Psychrophilic Habitats; Miteva 2008). In the following we focus on what is currently known about the diversity of glacial microbes, discuss the glacial environment as a habitat or archive and the longevity of microbes in ice.

\section{Diversity of Microbial Species Immured in Glacial Ice}

Glacial ice sheets entrap and preserve aerosolized biological material (i.e., insects, plant fragments, seeds, pollen grains, fungal spores and microorganisms) deposited in snowfall. The presence of viable bacteria and fungi in ancient glacier ice has been widely documented in polar and non-polar locations (e.g., Abyzov et al. 1993, 1998; Christner et al. 2000, 2003, 2006; Miteva and Brenchley 2005; Bidle et al. 2007; D’Elia et al. 2009; Miteva et al. 2009). Recent reviews by Priscu and Christner (2004) and Miteva (2008), and Christner et al. (2008c) and Priscu et al. (2008), provide good detailed overviews of the diversity of bacteria reported in a range of glacial and subglacial environments. Remarkably, many isolates obtained from geographically diverse glacier samples of polar and non-polar origin belong to the same bacterial genera (summarized in $>$ Table 6.3.2), including representatives of the Actinobacteria, Firmicutes, Proteobacteria and Bacteriodetes (Miteva 2008). Isolates of the Actinobacteria and Firmicutes are usually found to be predominant, followed by members of the Proteobacteria and Bacteroidetes. Studies that have succeeded in characterizing glacial microbial communities directly through culture-independent 16S rRNA based methods found sequences primarily relating to the same groups (Miteva 2008).

Microorganisms entrapped at increasing depth, and therefore, increasing age in glacier ice remain viable for hundreds of thousands (Abyzov et al. 1993, 1998; Christner et al. 2003, 2006; Miteva and Brenchley 2005) to perhaps millions of years (Bidle et al. 2007). Metagenomic analysis of a primarily bacterial assemblage in glacial ice from the German Alps indicates the potential for high metabolic diversity and molecular evidence for adaptations to increase survival at low temperature and during freezing (Simon et al. 2009). Some of the ice-related phenotypes found in species deposited in glacial environments may even have a role in precipitation generation and/or their precipitation from the atmosphere in snowfall (e.g., Christner et al. 2008a, b). Comprehensive studies of microbial assemblages immured chronologically within an ice core provide a unique approach to geobiology, e.g., by examining the influence of climate conditions on the species that were distributed in the atmosphere at different times in history (e.g., Christner et al. 2000; Miteva et al. 2009). Miteva et al. (2009) used a molecular approach to study the microbial assemblage in the GISP 2D (Greenland) ice core and found that higher bacterial and fungal diversity in ice deposited during cold climate conditions. Efforts to characterize the unique properties of psychrophiles from glaciers and other permanently frozen environments have increased significantly in recent years, and an assortment of properties have been identified that would be useful to cells that persist in a frozen matrix. Loveland-Curtze et al. (2010) described the species Chryseobacterium greenlandense, which was isolated from a depth of 3,043 $\mathrm{m}$ in the GISP 2D (Greenland) ice core. The small cells $\left(<0.1 \mathrm{~mm}^{3}\right)$ of this species enable a high cell surface-to-volume ratio, which enhances nutrient uptake and diffusion of substances throughout the cell. A species in the genus Chryseobacterium has also been reported from a deep Antarctic ice core (3,519 $\mathrm{m}$ in the Vostok ice core) that has the ability to alter the physical structure of ice (Raymond et al. 2008). This microbe produces an extracellular protein which binds to the 
Table 6.3.2

Examples of bacteria isolated from various polar and nonpolar glacial ices

\begin{tabular}{|c|c|c|c|}
\hline Phylum & Genus & Source & Reference \\
\hline Actinobacteria & Arthrobacter & $\begin{array}{l}\text { Antarctica, China, } \\
\text { Greenland, and } \\
\text { New Zealand }\end{array}$ & $\begin{array}{l}\text { Christner et al. (2000), Miteva et al. } \\
\text { (2004), Foght et al. (2004), Xiang } \\
\text { et al. (2005) }\end{array}$ \\
\hline Actinobacteria & Clavibacter & China and Bolivia & $\begin{array}{l}\text { Christner et al. (2000), Xiang et al. } \\
(2005)\end{array}$ \\
\hline Actinobacteria & Mycobacterium & $\begin{array}{l}\text { Bolivia and } \\
\text { Greenland }\end{array}$ & $\begin{array}{l}\text { Christner et al. (2000), Miteva et al. } \\
(2004)\end{array}$ \\
\hline Alphaproteobacteria & Methylobacterium & $\begin{array}{l}\text { Antarctica, } \\
\text { Greenland, and } \\
\text { China }\end{array}$ & $\begin{array}{l}\text { Christner et al. }(2000,2001,2008) \text {, } \\
\text { Miteva et al. }(2004,2009)\end{array}$ \\
\hline Alphaproteobacteria & Sphingomonas & $\begin{array}{l}\text { Antarctica, } \\
\text { Greenland, China, } \\
\text { and New Zealand }\end{array}$ & $\begin{array}{l}\text { Christner et al. (2000, 2001, 2008), } \\
\text { Foght et al. (2004), Miteva et al. } \\
\text { (2004), Xiang et al. (2005), Miteva } \\
\text { et al. (2009) }\end{array}$ \\
\hline Gammaproteobacteria & Acinetobacter & $\begin{array}{l}\text { Antarctica, Bolivia, } \\
\text { and China }\end{array}$ & $\begin{array}{l}\text { Christner et al. (2000), Xiang et al. } \\
(2005)\end{array}$ \\
\hline Bacteroidetes & Chryseobacterium & $\begin{array}{l}\text { Antarctica and } \\
\text { Greenland }\end{array}$ & $\begin{array}{l}\text { Raymond et al. (2008), } \\
\text { Loveland-Curtze et al. (2010) }\end{array}$ \\
\hline Bacteroidetes & Flavobacterium & $\begin{array}{l}\text { Antarctica, China, } \\
\text { and New Zealand }\end{array}$ & $\begin{array}{l}\text { Christner et al. (2000), Zhu et al. } \\
\text { (2003), Foght et al. (2004), Xiang } \\
\text { et al. (2005), Zhang et al. (2006) }\end{array}$ \\
\hline Firmicutes & Bacillus & $\begin{array}{l}\text { Antarctica, Bolivia, } \\
\text { China, and } \\
\text { Greenland }\end{array}$ & $\begin{array}{l}\text { Abyzov et al. (1993), Christner } \\
\text { et al. (2000), Miteva and Brenchley } \\
\text { (2005), Xiang et al. (2005), Miteva } \\
\text { et al. (2009) }\end{array}$ \\
\hline Firmicutes & Exiguobacterium & $\begin{array}{l}\text { Bolivia, Greenland, } \\
\text { and India }\end{array}$ & $\begin{array}{l}\text { Christner et al. (2000), Miteva et al. } \\
\text { (2004), Chaturvedi and Shivaji } \\
(2006)\end{array}$ \\
\hline Firmicutes & Paenibacillus & $\begin{array}{l}\text { Antarctica, Bolivia, } \\
\text { China, Greenland, } \\
\text { and New Zealand }\end{array}$ & $\begin{array}{l}\text { Christner et al. (2000, 2001), Foght } \\
\text { et al. (2004), Miteva et al. (2004), } \\
\text { Xiang et al. (2005) }\end{array}$ \\
\hline Firm & Plan & Bolivia and China & $\begin{array}{l}\text { Christner et al. (2000), Xiang et al. } \\
(2005)\end{array}$ \\
\hline
\end{tabular}

prism faces of ice crystals and prevents recrystallization, i.e., an ice-binding protein. Bacteria in the genus Psychrobacter have been recovered frequently in enrichments targeting heterotrophs in icy environments (e.g., Gilichinsky et al. 2003, 2005; Bakermans et al. 2003, 2006; Mosier et al. 2007). In particular, studies of Psychrobacter species have provided valuable insight into their growth (Bakermans et al. 2003) and gene and protein expression patterns (Bakermans et al. 2007; Bergholz et al. 2009) at subzero temperatures, as well as their capability to metabolize within an ice matrix (Christner 2002; Amato and Christner 2009a). 


\section{Glacial Ice: Archive or Habitat?}

It was initially assumed that cells surviving within ancient glacial ice did so in a state of anabiosis (e.g., Abyzov et al. 1998). In freshwater and saline ice, various studies have shown that cells are physically located in the aqueous interstitial veins that exist at ice grain boundaries (Junge et al. 2004; Mader et al. 2006; Amato et al. 2009b; > Figs. 6.3.1 and ( 6.3.3), supporting Price's (2000) hypothesis that ice veins provide a habitat for cells in glacial ice. Sub-nanometer thin films of liquid water have been reported down to temperatures of $-196^{\circ} \mathrm{C}$ (Pearson and Derbyshire 1974); however, the increased ionic concentration of unfrozen water at decreasing temperatures in ice likely constrains biological activity by creating chemical conditions incompatible with a microorganism's physiology. Laboratory studies have provided a new perspective on the potential for functional biological processes under frozen conditions (Carpenter et al. 2000; Rivkina et al. 2000; Christner 2002; Amato et al. 2009b). As of yet, the low temperature limit for metabolism is not known and is probably $<-40^{\circ} \mathrm{C}$ (e.g., Junge et al. 2006; Panikov et al. 2006; Amato and Christner 2009). Hence, the physiological potential for metabolism under conditions in glacial ice has been established.

Analysis of the gases entrapped in ice cores from Antarctica, Bolivia, and Greenland have revealed ice horizons where the $\mathrm{CO}_{2}, \mathrm{~N}_{2} \mathrm{O}$ and $\mathrm{CH}_{4}$ concentrations are significantly elevated above atmospheric concentrations, and a number of investigators have concluded that these anomalies are the result of in situ microbial activity (Sowers 2001; Campen et al. 2003; Tung et al. 2006). Gas anomalies are commonly observed in basal ice, and Souchez et al. (1995) suggest that anomalously high $\mathrm{CO}_{2}$ and $\mathrm{CH}_{4}$ concentrations entrapped within GRIP silty ice may have originated from "flow-induced mixing"; however, in situ production of these gases still remains a plausible explanation (e.g., Tung et al. 2006). If microbial consortia remain metabolically active in the ice, then the World's glaciers represent active biomes, substantially expanding the known realm for life in the biosphere.

\section{Limits to Longevity in Glacial Ice}

For a microorganism to remain viable over an extended period of frozen dormancy, the macromolecular damage (e.g., to DNA) incurred by the cell must not exceed a level where effective repair is no longer possible. Viable microorganisms have been recovered from ancient glacial ice (Christner et al. 2003; Miteva and Brenchley 2005; Bidle et al. 2007) and permafrost (Vishnivetskaya et al. 2006; Gilichinsky et al. 2007; Johnson et al. 2007) samples ranging from hundreds-of-thousands to millions of years old. McKay (2001) predicted that background ionizing radiation in terrestrial permafrost (i.e., from the decay of potassium-40, thorium-232, and uranium-238) would inactivate dormant bacteria in 10-100 million years. In $>$ Fig. 6.3.4, we predicted cellular damage based on the introduction of lethal DNA double-stranded breaks (DSB) to the genome from ionizing radiation dosages in the Antarctic subsurface and "low background" environments ( $10^{-3}$ to $10^{-4} \mathrm{~Gy} \mathrm{y}^{-1}$; Luckey 1991). The susceptibility of bacteria to ionizing radiation is expressed as the number of DNA DSB at the $\mathrm{D}_{37}$, which is the ionizing radiation dosage at which $37 \%$ of the cells survive, which on average, is sufficient to inactivate a single colony-forming unit of the irradiated population (Battista 1997). These data and related calculations imply that it would take 300,000-3,000,000 years of exposure to acquire an ionizing radiation dosage equivalent to the $\mathrm{D}_{37}$ of Escherichia coli, but a radiation-resistant bacterium such as Deinococcus radiodurans could remain in the ice for 


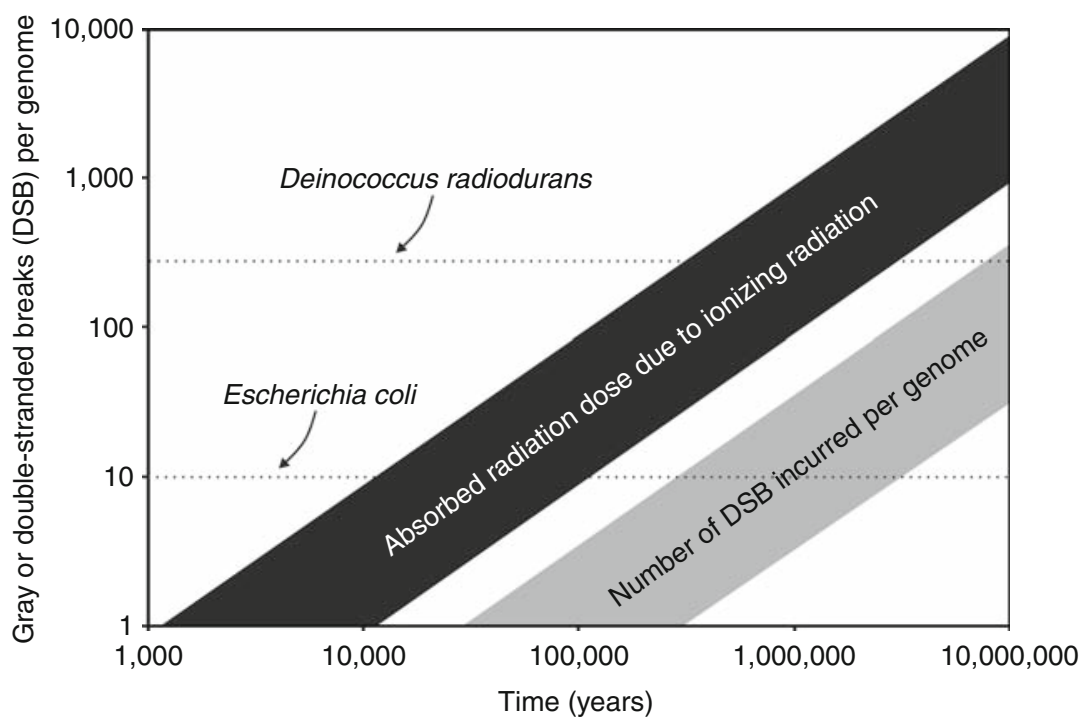

Fig. 6.3.4

Estimated number of DNA double-stranded breaks (DSB) in a microbial genome over time from ionizing radiation sources within glacial ice. Data range estimates for dosage from Luckey (1991). Values for DNA DSB damage due to ionizing radiation dosage (1 DSB per $30 \mathrm{~Gy}$ ) from Battista (1997). The dotted horizontal lines are examples for the number of DNA DSB at the D37 for Escherichia coli and Deinococcus radiodurans

$>8,250,000$ years before reaching the $\mathrm{D}_{37}(\diamond$ Fig. 6.3.4). Our calculations are consistent with the exponential decline in average community DNA size $\left(\mathrm{t}_{1 / 2}=1.1\right.$ million years) observed by Bidle et al. (2007) in a time sequence of ice samples up to 8 million years old. It is important to note that these estimates assume that microorganisms are metabolically dormant when entrapped within frozen matrices, and therefore, are incapable of repairing cellular damage as it is incurred.

Christner (2002a) demonstrated the ability of bacteria to conduct DNA synthesis at $-15^{\circ} \mathrm{C}$ and hypothesized that the metabolic activity observed was directed towards repairing damage sustained during the freezing process (i.e., DNA breakage) or for maintenance metabolism (Price and Sowers 2004). Johnson et al. (2007) provided evidence for DNA repair in permafrost samples up to 600,000 years old and concluded that "bacteria with an active DNA repair mechanism are most likely to persevere." If laboratory measurements of microbial metabolism under frozen conditions are a true reflection of their physiological potential in natural icy environments, a slow metabolic rate may be sufficient to offset cellular damage, allowing survival in frozen substrates for extended time frames. In contrast, ionizing radiation-resistant bacteria, which are often also resistant to UV radiation and desiccation (i.e., Rainey et al. 2005), might be capable of remaining viable in the absence of metabolism due to their extremely efficient DNA repair mechanisms (e.g., Battista 1997). Testing the ionizing radiation tolerances of viable microorganisms recovered from ancient glacial ice would provide a means to formulate hypotheses regarding the particular means of survival (i.e., dormancy and efficient DNA repair versus metabolic activity and repair under frozen conditions) used by species that survive for geological timeframes in ice. 


\section{Conclusions}

Sea ice and glacier ice harbor unique microbial communities with many steno- and euro psychrophilic members. These psychrophiles exhibit a rich diversity with many of the same groups represented in both habitats indicating that environmental conditions in the ice (temperature, concentration of solutes, etc.) select for certain types of organisms. It has now been shown that psychrophilic microbes residing both in saline and freshwater ice veins might not be merely persisting but can also carry out low levels of metabolic activity. For glacial ice microbes, this could possibly allow for DNA damage repair while being immured in the ice over thousands to hundreds of thousands and possibly even millions of years.

\section{Cross-References}

จ 6.4 Adaptation Mechanisms of Psychrotolerant Bacterial Pathogens

จ 6.5 Ecological Distribution of Microorganisms in Terrestrial, Psychrophilic Habitats

○ 6.7 Psychrophilic Enzymes: Cool Responses to Chilly Problems

○ 9.4 Genetics, Genomics, Evolution

\section{References}

Amann RI, Ludwig W, Schleifer KH (1995) Phylogenetic identification and in situ detection of individual microbial cells without cultivation. Microbiol Rev 59:143-169

Arrigo KR, Mock T, Lizotte MP (2010) Primary producers and sea ice. In: Thomas DN, Dieckmann GS (eds) Sea ice: an introduction to its physics, chemistry, biology, and geology. Blackwell, Oxford, pp 283-375

Auman AJ, Breezee JL, Gosink JJ, Kämpfer P, Staley JT (2006) Psychromonas ingrahamii, sp. nov., a novel gas vacuolate, psychrophilic bacterium isolated from Arctic polar sea ice. Int J Syst Evol Microbiol 56:1001-1007

Auman AJ, Breezee JL, Gosink JJ, Kämpfer P, Staley JT (2010) Psychromonas boydii, sp. nov., a novel gas vacuolate, psychrophilic bacterium isolated from an Arctic sea ice core from Point Barrow, Alaska. Int J Syst Evol Microbiol 60:84-92

Baas-Becking LGM (1934) Geobiologie of Inleiding Tot de Milieukunde. W. P. Van Stockum \& Zoon, N.V., Den Haag, The Netherlands

Bowman JP, McCammon SA, Brown MV, McMeekin TA (1997a) Diversity and association of psychrophilic bacteria in Antarctic sea ice. Appl Environ Microbiol 63:3068-3078

Bowman JP, McCammon SA, Brown MV, Nichols PD, McMeekin TA (1997b) Psychroserpens burtonensis gen nov., sp. nov., and Gelidibacter algens gen. nov., sp. nov., psychrophilic bacteria isolated from
Antarctic lacustrine and sea ice habitats. Int J Syst Bacteriol 47:670-677

Bowman JP, McCammon SA, Lewis T, Skerrat JH, Brown JL, Nichols DS, McMeekin TA (1998a) Psychroflexus torquis gen. nov., sp. nov., a psychrophilic species from Antarctic sea ice, and reclassification of Flavobacterium gondwanense (Dobson et al. 1993) as Psychroflexus gondwanense gen. nov. comb. nov. Microbiology 144:1601-1609

Bowman JP, Gosink JJ, McCammon SA, Lewis TE, Nichols DS et al (1998b) Colwellia demingiae sp. nov., Colwellia hornerae, sp. nov. Colwellia rossensis sp. nov. and Colwellia psychrotropica sp. nov. psychrophilic Antarctic species with the ability to synthesize docosaheaenoic acid (22:6w3). Int J Syst Bacteriol 48:1171-1180

Bowman JP (2008) Genomic analysis of psychrophilic prokaryotes. In: Margesin R et al (eds) Psychrophiles: from biodiversity to biotechnology. Springer, Berlin/ Heidelberg, pp 265-284

Breezee J, Cady N, Staley JT (2004) Sub-zero growth of the sea ice bacterium, "Psychromonas ingrahamii." Microb Ecol 47:300-305

Brinkmeyer R, Glöckner FO, Helmke E, Amann R (2004) Predominance of beta-proteobacteria in summer melt pools on Arctic pack ice. Limnol Oceanogr 49:1013-1021

Brinkmayer R, Knittel K, Ruegens H, Weyland R, Amann R, Helmke E (2003) Diversity and community 
structure of bacterial communities in Arctic versus Antarctic sea ice. Appl Environ Microbiol 69:6610-6619

Brown MV, Bowman JP (2001) A molecular phylogenetic survey of sea-ice microbial communities (SIMCO). FEMS Microbiol Ecol 35:267-275

Delille D (1993) Seasonal changes in the abundance and composition of marine heterotrophic bacterial communities in an Antarctic coastal area. Polar Biol 13:463-470

Delille D, Rosiers C (1996) Seasonal changes of Antarctic marine bacterioplankton and sea ice bacterial assemblages. Polar Biol 16:27-34

Delille D, Fiala M, Kuparinen J, Kuosa H, Plessis C (2002) Seasonal changes in microbial biomass in the firstyear ice of the Terre Adelie area (Antarctica). Aquat Microb Ecol 28:257-265

Deming JW (2010) Sea ice bacteria and viruses. In: Thomas DN, Dieckmann GS (eds) Sea ice: an introduction to its physics, chemistry, biology, and geology. Blackwell, Oxford, pp 247-282

Deming JW, Eicken H (2007) Life in ice. In: Sullivan WT, Baross JA (eds) Planets and life: the emerging science of astrobiology. Cambridge University Press, Cambridge, pp 292-312

Eicken H (1992) The role of sea ice in structuring Antarctic ecosystems. Polar Biol 12:3-13

Garneau ME, Vincent WF, Terrado R, Lovejoy C (2009) Importance of particle-associated bacterial heterotrophy in a coastal Arctic ecosystem. J Mar Syst 75:185-197

Garrison DL, Close AR (1993) Winter ecology of the seaice biota in Weddell Sea pack ice. Mar Ecol Prog Ser 96:17-31

Garrison DL, Ackley SF, Buck KR (1983) A physical mechanism for establishing algal populations in frazil ice. Nature 306:363-365

Gleitz M, vd Loeff MR, Thomas DN, Dieckmann GS, Millero FJ (1995) Comparison of summer and winter inorganic carbon, oxygen and nutrient concentrations in Antarctic sea ice brine. Mar Chem 51:81-91

Gleitz M, Grossmann S, Scharek R, Smetacek V (1996) Ecology of diatom and bacterial assemblages in water associated with melting summer sea ice in the Weddell Sea, Antarctica. Antarct Sci 8:135-146

Golden KM, Ackley SF, Lytle VI (1998) The percolation phase transition in sea ice. Science 282:2238-2241

Gosink J, Irgens RL, Staley JT (1993a) Vertical distribution of bacteria from Arctic sea ice. FEMS Microbiol Ecol 102:85-90

Gosink J, Staley JT (1995) Biodiversity of gas vacuolate bacteria from Antarctic sea ice and water. Appl Environ Microbiol 61:3486-3489

Gosink J, Herwig RP, Staley JT (1997) Octadecobacter arcticus, gen. nov., sp. nov. and $\mathrm{O}$. antarcticus sp. nov., nonpigmented, psychrophilic gas vacuolate bacteria from polar sea ice and water. Syst Appl Microbiol 20:356-365

Gosink JJ, Irgens RL, Staley JT (1993b) Vertical distribution of bacteria in Arctic sea ice. FEMS Microbiol Ecol 102:85-90

Gosink JJ, Woese CR, Staley JT (1998) Polaribacter gen. nov, with three new species, $P$. irgensii sp. nov., P. franzmannii sp. nov., and P. filamentus sp. nov., gas vacuolate polar marine bacteria of the Cytophaga/ Flavobacterium/Bacteroides Group and reclassification of "Flectobacillus glomeratus" as Polaribacter glomeratus. Int J Syst Bacteriol 48:223-235

Grossi SM, Kottmeier ST, Sullivan CW (1984) Sea ice microbial communities. III. Seasonal abundance of microalgae and associated bacteria. Microb Ecol $10: 231-242$

Helmke E, Weyland H (1995) Bacteria in sea ice and underlying water of the Eastern Weddell Sea in midwinter. Mar Ecol Prog Ser 117:269-287

Horner RA (1985) Sea ice biota. CRC Press, Boca Raton Irgens RL, Gosink JJ, Staley JT (1996) Polaromonas vacuolata, nov. gen. et sp., gas vacuolate bacteria from sea waters of Antarctica. Int J Syst Bacteriol $46: 822-826$

Irgens RL, Suzuki I, Staley JT (1989) Gas vacuolate bacteria obtained from marine waters of Antarctica. Curr Microbiol 18:262-265

Junge K, Gosink JJ, Hoppe HG, Staley JT (1998) Arthrobacter, Brachybacterium and Planococcus isolates identified from Antarctic sea ice brine. Description of Planococcus momeekinii, sp. nov. Syst Appl Microbiol 21:306-314

Junge K, Imhoff JF, Staley JT, Deming JW (2002) Phylogenetic diversity of numerically important bacteria in Arctic sea ice. Microb Ecol 43:315-328

Junge K, Eicken H, Deming JW (2004a) Bacterial activity at $-2^{\circ} \mathrm{C}$ to $-20^{\circ} \mathrm{C}$ in Arctic wintertime sea ice. Appl Environ Microbiol 70:550-557

Kellogg C, Deming JW (2009) Comparison of free-living, suspended particle, and aggregate-associated bacterial and archaeal communities in the Laptev Sea. Aquat Microb Ecol 57:1-18

Collins RE, Carpenter S, Deming JW (2008) Spatial and temporal dynamics of particles, bacteria, and extracellular polymeric substances in Arctic winter sea ice. J Mar Syst 74:902-917

Collins RE, Rocap G, Deming JW (2010) Persistence of bacterial and archaeal communities in sea ice through an Arctic winter. Environ Microbiol 12:1828-1841

Huston AL, Krieger-Brockett BB, Deming JW (2000) Remarkably low temperature optima for extracellular enzyme activity from Arctic bacteria and sea ice. Environ Microbiol 2:383-388 
Kaartokallio H, Tuomainen J, Kuosa H, Kuparinen J, Martikainen PJ, Servomaa K (2008) Succession of sea-ice bacterial communities in the Baltic Sea fast ice. Polar Biol 31:783-793

Kottmeier ST, Sullivan CW (1987) Late winter primary production and bacterial production in sea ice and seawater west of the Antarctic Peninsula. Mar Ecol Prog Ser 36:287-298

Krembs C, Eicken H, Junge K, Deming JW (2002) High concentrations of exopolymeric substances in Arctic winter sea ice: implications for the polar ocean carbon cycle and cryoprotection of diatoms. Deep Sea Res I 49:2163-2181

Krembs C, Deming JW (2008) The role of exopolymers in microbial adaptation to sea ice. In: Margesin R, Schinner F, Marx JC, Gerday C (eds) Psychrophiles: from biodiversity to biotechnology. Springer, Berlin, pp 247-264

Kirchman DL, Moran XAG, Ducklow H (2009) Microbial growth in the polar oceans- role of temperature and potential impact of climate change. Nat Rev Microbiol 7:451-459

Laurion I, Demers S, Vezina AF (1995) The microbial food web associated with the ice algal assemblage: biomass and bacteriovory of nanoflagellate protozoans in Resolute Passage (High Canadian Arctic). Mar Ecol Prog Ser 120:77-87

Legendre L, Ackley SF, Dieckmann GS, Gulliksen B, Horner R, Hoshiai T, Melnikov IA, Reeburgh WS, Spindler M, Sullivan CW (1992) Ecology of sea ice biota 2. Global significance. Polar Biol 12:429-444

Maranger R, Bird DF, Juniper SK (1994) Viral and bacterial dynamics in Arctic sea-ice during the spring algal bloom near Resolute, NWT, Canada. Mar Ecol Prog Ser 111:121-127

Meiners K, Gradinger R, Fehling J, Civitarese G, Spindler M (2003) Vertical distribution of exopolymer particles in sea ice of the Fram Strait (Arctic) during autumn. Mar Ecol Prog Ser 248:1-13

Methé BA, Nelson KE, Deming JW, Momen B, Melamud E, Zhang X, Moult J, Madupu R, Nelson WC, Dodson RJ, Brinkac LM, Daugherty SC, Durkin AS, DeBoy RT, Kolonay JF, Sullivan SA, Zhou L, Davidsen TM, Wu M, Huston AL, Lewis M, Weaver B, Weidman JF, Khouri H, Utterback TR, Feldblyum TV, Fraser CM (2005) The psychrophilic lifestyle as revealed by the genome sequence of Colwellia psychrerythraea $34 \mathrm{H}$ through genomic and proteomic analyses. Proc Natl Acad Sci USA 102:10913-10918

Mock T, Thomas DN (2005) Recent advances in sea-ice microbiology. Environ Microbiol 7:605-619

Palmisano GA, Garrison DL (1993) Microorganisms in Antarctic sea ice. In: Friedmann EI (ed) Antarctic microbiology. Wiley-Liss, New York, pp 167-219
Petri R, Imhoff JF (2001) Genetic analysis of sea-ice bacterial communities of the Western Baltic Sea using an improved double gradient method. Polar Biol 24:252-257

Petrich C, Eicken H (2010) Growth, structure and properties of sea ice. In: Thomas DN, Dieckmann GS (eds) Sea ice: an introduction to its physics, chemistry, biology, and geology. Blackwell, Oxford, pp 23-78

Rysgaard S, Glud RN (2004) Anaerobic N 2 production in Arctic sea ice. Limnol Oceanogr 49:86-94

Rysgaard S, Glud RN, Sejr MK, Blicher ME, Stahl HJ (2008) Denitrification activity and oxygen dynamics in Arctic sea ice. Polar Biol 31:527-537

Riley M, Staley JT, Danchin TSA, Wang TZ, Brettin TS, Hauser LJ, Land ML, Thompson LS (2008) Genomics of an extreme psychrophile Psychromonas ingrahamii. BMC Genomics 9:210

Serreze MC, Holland MM, Stroeve J (2007) Perspectives on the Arctic's shrinking sea-ice cover. Science 315:1533-1536

Staley JT, Junge K, Deming JW (2001) And some like it cold: sea ice microbiology. In: Staley JT, Reysenbach AL (eds) Biodiversity of life: foundation of earth's biosphere. Wiley-Liss, New York, pp 423-438

Staley JT (1980) The gas vacuole: An early organelle of prokaryote motility? Orig Life 10:111-116

Staley JT (1997) Biodiversity: are microbial species threatened? Curr Opin Biotechnol 8:340-345

Staley JT, Irgens RL, Herwig RP (1989) Gas vacuolate bacteria found in Antarctic sea ice with ice algae. Appl Environ Microbiol 55:1033-1036

Staley JT, Gosink J, Irgens RL, Van Neerven ARW (1994) Gas vacuolate heterotrophic bacteria. In: Guerrero R, Pedros-Alio C (eds) Trends in microbial ecology, Spanish Society for Microbiology, pp 527-530

Staley JT, Gosink JJ, Hedlund BP (1996) New bacterial taxa from polar sea ice communities and culture collections. In: Samson RA, Stalpers JA, van der Mei D, Stouthamer AH (eds) Culture collections to improve the quality of life. Ponsen and Looyen, Wageningen, pp 114-118

Staley JT, Konopka AL (1985) Measurement of in situ activities of heterotrophic microorganisms in terrestrial habitats. Annu Rev Microbiol 39:321-346

Staley JT, Konopka AL, Dalmasso JP (1987) Spatial and temporal distribution of Caulobacter spp. in two mesotrophic lakes. FEMS Microbiol Ecol 45:1-6

Staley JT, Lehmicke L, Palmer FE, Peet R, Wissmar RC (1982) Impact of Mt. St. Helens' eruption on bacteriology of lakes in blast zone. Appl Environ Microbiol 43:664-670

Stroeve JC, Serreze MC, Fetterer F, Arbetter T, Meier W, Maslanik J, Knowles K (2005) Tracking the Arctic's shrinking ice cover: Another extreme September minimum in 2004. Geophys Res Lett 32:L04501 
Sullivan CW, Palmisano AC (1984) Sea ice microbial communities: Distribution, abundance, and diversity of ice bacteria in McMurdo Sound, Antarctica, in 1980. Appl Environ Microbiol 47:788-795

Thomas DN, Dieckmann GS (2002) Antarctic sea ice-a habitat for extremophiles. Science 295:641-644

Thomas DN, Dieckman GS (eds) (2010) Sea ice: an introduction to its physics, chemistry, biology, and geology. Blackwell, Oxford, p 621

Weissenberger J, Grossmann S (1998) Experimental formation of sea ice: importance of water circulation and wave action for incorporation of phytoplankton and bacteria. Polar Biol 20:178-188

Wells LE, Deming JW (2003) Abundance of Bacteria, the Cytophaga-Flavobacterium cluster and Archaea in cold oligotrophic waters and nepheloid layers of the Northwest Passage, Canadian Archipelago. Aquat Microb Ecol 31:19-31

Wells LE, Deming JW (2006a) Characterization of a coldactive bacteriophage on two psychrophilic marine hosts. Aquat Microb Ecol 45:15-29

Wells LE, Deming JW (2006b) Effects of temperature, salinity and clay particles on inactivation and decay of cold-active marine Bacteriophage 9A. Aquat Microb Ecol 45:31-39

Wells LE, Deming JW (2006c) Modelled and measured dynamics of viruses in Arctic winter sea-ice brines. Environ Microbiol 8:1115-1121

\section{BC's Refs}

Abyzov SS (1993) Microorganisms in the Antarctic ice. In: Friedmann EI (ed) Antarctic microbiology. Wiley-Liss, New York, pp 265-295

Abyzov SS, Mitskevich IN, Poglazova MN (1998) Microflora of the deep glacier horizons of central Antarctica. Microbiology (Moscow) 67:66-73

Amato P, Christner BC (2009) Energy metabolism response to low temperature and frozen conditions in Psychrobacter cryohalolentis. Appl Environ Microbiol 75:711-718

Amato P, Doyle SM, Christner BC (2009) Macromolecular synthesis by yeasts under frozen conditions. Environ Microbiol 11:589-596

Bakermans C, Tsapin AI, Souza-Egipsy V, Gilichinsky DA, Nealson KH (2003) Reproduction and metabolism at $-10^{\circ} \mathrm{C}$ of bacteria isolated from Siberian permafrost. Environ Microbiol 5:321-326

Bakermans C, Ayala-del-Río HL, Ponder MA, Vishnivetskaya T, Gilichinsky D, Thomashow MF, Tiedje JM (2006) Psychrobacter cryohalolentis sp. nov. and Psychrobacter arcticus sp. nov., isolated from Siberian permafrost. Int J Syst Evol Microbiol 56:1285-1291

Bakermans C, Tollaksen SL, Giometti CS, Wilkerson C, Tiedje JM, Thomashow MF (2007) Proteomic analysis of Psychrobacter cryohalolentis K5 during growth at subzero temperatures. Extremophiles 11:343-354

Battista JR (1997) Against all odds: the survival strategies of Deinococcus radiodurans. Annu Rev Microbiol 51:203-224

Bergholz PW, Bakermans C, Tiedje JM (2009) Psychrobacter arcticus 273-4 uses resource efficiency and molecular motion adaptations for subzero temperature growth. J Bacteriol 191:2340-2352

Bidle KD, Lee SH, Marchant DR, Falkowski PG (2007) Fossil genes and microbes in the oldest ice on Earth. Proc Natl Acad Sci 104:13455-13460

Campen RK, Sowers T, Alley RB (2003) Evidence of microbial consortia metabolizing within a lowlatitude mountain glacier. Geology 31:231-234

Carpenter EJ, Lin S, Capone DG (2000) Bacterial activity in South Pole snow. Appl Environ Microbiol 66:4514-4517

Chaturvedi P, Shivaji S (2006) Exiguobacterium indicum sp. nov. a psychrophilic bacterium from the Hamta glacier of the Himalayan mountain ranges of India. Int J Syst Evol Microbiol 56:2765-2770

Christner BC, Mosley-Thompson E, Thompson LG, Zagorodnov V, Sandman K, Reeve JN (2000) Recovery and identification of viable bacteria immured in glacial ice. Icarus 144:479-485

Christner BC, Mosley-Thompson E, Thompson LG, Reeve JN (2001) Isolation of bacteria and $16 \mathrm{~S}$ rDNAs from Lake Vostok accretion ice. Environ Microbiol 3:570-577

Christner BC (2002) Incorporation of DNA and protein precursors into macromolecules by bacteria at $-15^{\circ} \mathrm{C}$. Appl Environ Microbiol 68:6435-6438

Christner BC, Mosley-Thompson E, Thompson LG, Reeve JN (2003) Bacterial recovery from ancient ice. Environ Microbiol 5:433-436

Christner BC, Royston-Bishop G, Foreman CM, Arnold BR, Tranter M, Welch KA, Lyons WB, Tsapin AI, Studinger M, Priscu JC (2006) Limnological conditions in Subglacial Lake Vostok, Antarctica. Limnol Oceanogr 51:2485-2501

Christner BC, Morris CE, Foreman CM, Cai R, Sands DC (2008a) Ubiquity of biological ice nucleators in snowfall. Science 319:1214

Christner BC, Cai R, Morris CE, McCarter KS, Foreman CM, Skidmore ML, Montross SN, Sands DC (2008b) Geographic, seasonal, and precipitation chemistry influence on the abundance and activity of biological ice nucleators in rain and snow. Proc Natl Acad Sci USA 105:18854-18859

Christner BC, Skidmore ML, Priscu JC, Tranter M, Foreman CM (2008c) Bacteria in subglacial environments. In: Margesin R, Schinner F, Marx JC, Gerday C (eds) Psychrophiles: from biodiversity to biotechology. Springer, New York, pp 51-71 
D’Elia TR, Veerapaneni V, Theraisnathan RS (2009) Isolation of fungi from Lake Vostok accretion ice. Mycologia 101:751

Foght J, Aislabie J, Turner S, Brown CE, Ryburn J, Saul DJ, Lawson W (2004) Culturable bacteria in subglacial sediments and ice from two southern hemisphere glaciers. Microb Ecol 47:329-340

Gilichinsky D, Rivkina E, Shcherbakova V, Laurinavichuis K, Tiedje J (2003) Supercooled water brines within permafrost - An unknown ecological niche for microorganisms: a model for astrobiology. Astrobiology 3:331-341

Gilichinsky D, Rivkina E, Bakermans C, Shcherbakova V, Petrovskaya L, Ozerskaya N, Ivanushkina N, Kochkina G, Laurinavichuis K, Pecheritsina S, Fattakhova R, Tiedje JM (2005) Biodiversity of cryopegs in permafrost. FEMS Microbiol Ecol 53:117-128

Gilichinsky DA, Wilson GS, Friedmann EI, Mckay CP, Sletten RS, Rivkina EM, Vishnivetskaya TA, Erokhina LG, Ivanushkina NE, Kochkina GA, Shcherbakova VA, Soina VS, Spirina EV, Vorobyova EA, Fyodorov-Davydov DG, Hallet B, Ozerskaya SM, Sorokovikov VA, Laurinavichyus KS, Shatilovich AV, Chanton JP, Ostroumov VE, Tiedje JM (2007) Micobrobial populations in Antarctic permafrost: biodiversity, state, age, and implication for astrobiology. Astrobiology 7:275-311

Johnson SS, Hebsgaard MB, Christensen TR, Mastepanov M, Nielsen R, Munch K, Brand T, Gilbert MT, Zuber MT, Bunce M, Rønn R, Gilichinsky D, Froese D, Willerslev E (2007) Ancient bacteria show evidence of DNA repair. Proc Natl Acad Sci 36:14401-14405

Junge K, Eicken H, Deming JW (2004b) Bacterial activity at $-2^{\circ} \mathrm{C}$ to $-20^{\circ} \mathrm{C}$ in Arctic wintertime sea ice. Appl Environ Microbiol 70:550-557

Junge K, Eicken H, Swanson BD, Deming JW (2006) Bacterial incorporation of leucine into protein down to $-20^{\circ} \mathrm{C}$ with evidence for potential activity in sub-eutectic saline ice formations. Cryobiology 52:417-429

Loveland-Curtze J, Miteva V, Brenchley J (2010) Novel ultramicrobacterial isolates from a deep Greenland ice core represent a proposed new species, Chryseobacterium greenlandense sp. nov. Extremophiles 14:61-69

Luckey TD (1991) Radiation hormesis. CRC Press, Boca Raton

Mader HM, Wadham PME, JL WEW, Parkes RJ (2006) Subsurface ice as a microbial habitat. Geology 34:169-172

McKay CP (2001) The deep biosphere: lessons for planetary exploration. In: Fredrickson JK, Fletcher M (eds) Subsurface microbiology and biogeochemistry. Wiley-Liss, New York, pp 315-327
Miteva VI, Sheridan PP, Brenchley JE (2004) Phylogenetic and physiological diversity of microorganisms isolated from a deep Greenland glacier ice core. Appl Environ Microbiol 70:202-213

Miteva VI, Brenchley JE (2005) Detection and isolation of ultrasmall microorganisms from a 120, 000-YearOld Greenland glacier ice core. Appl Environ Microbiol 71:7806-7818

Miteva V (2008) Bacteria in snow and glacier ice. In: Margesin R, Schinner F, Marx JC, Gerday C (eds) Psychrophiles: from biodiversity to biotechology. Springer, New York, pp 31-50

Miteva V, Teacher C, Sowers T, Brenchley J (2009) Comparison of the microbial diversity at different depths of the GISP2 Greenland ice core in relationship to deposition climates. Environ Microbiol 11:640-656

Mosier A, Murray A, Fritsen CH (2007) Microbiota within the perennial ice cover of Lake Vida, Antarctica. FEMS Microbiol Ecol 59:274-288

Panikov NS, Flanagan PW, Oechel WC, Mastepanov MA, Christensen TR (2006) Microbial activity in soils frozen to below $-39^{\circ} \mathrm{C}$. Soil Biol Biochem 38:785-794

Pearson RT, Derbyshire W (1974) NMR studies of water adsorbed on a number of silica surfaces. J Colloid Interface Sci 46:232-248

Price PB (2000) A habitat for psychrophiles in deep Antarctic ice. Proc Natl Acad Sci 97:1247-1251

Price PB, Sowers T (2004) Temperature dependence of metabolic rates for microbial growth, maintenance, and survival. Proc Natl Acad Sci 101:4631-4636

Priscu JC, Christner BC (2004) Earth's icy biosphere. In: Bull AT (ed) Microbial diversity and bioprospecting. American Society for Microbiology Press, Washington, pp 130-145

Priscu JC, Tulaczyk S, Studinger M, Kennicutt MC II, Christner BC, Foreman CM (2008) Antarctic subglacial water: origin, evolution and microbial ecology. In: Vincent W, Laybourn-Parry J (eds) Polar limnology. Oxford University Press, Oxford, pp 119-135

Rainey FA, Ray K, Gatz FM, BZ NMF, Bagaley D, Rash BA, Park MJ, Earl AM, Shank NC, Small AM, Henk MC, Battista JR, Kämpfer P, da Costa MS (2005) Extensive diversity of ionizing-radiationresistant bacteria recovered from Sonoran Desert soil and description of nine new species of the genus Deinococcus obtained from a single soil sample. Appl Environ Microbiol 71:5225-5235

Raymond JA, Christner BC, Schuster SC (2008) An iceadapted bacterium from the Vostok ice core. Extremophiles 12:713-717

Rivkina EM, Friedmann EI, McKay CP, Gilichinsky DA (2000) Metabolic activity of permafrost bacteria below the freezing point. Appl Environ Microbiol 66:3230-3233 
Simon C, Wiezer A, Strittmatter AW, Daniel R (2009) Phylogenetic diversity and metabolic potential revealed in a glacier ice metagenome. Appl Environ Microbiol 75:7519-7526

Souchez R, Janssens M, Lemmens M, Stauffer B (1995) Very low oxygen concentration in basal ice from Summit, Central Greenland. Geophys Res Lett 22:2001-2004

Sowers $\mathrm{T}$ (2001) The $\mathrm{N}_{2} \mathrm{O}$ record spanning the penultimate deglaciation from the Vostok ice core. J Geograph Res 106:31903-31914

Tung HC, Price PB, Bramall NE, Vrdoljak G (2006) Microorganisms metabolizing on clay grains in 3-km-deep Greenland basal ice. Astrobiology 6:69-86

Vishnivetskaya TA, Petrova MA, Urbance J, Ponder M, Moyer CL, Gilichinsky DA, Tiedje JM (2006)
Bacterial community in ancient Siberian permafrost as characterized by culture and culture-independent methods. Astrobiology 6:400-414

Xiang S, Yao T, An L, Xu B, Wang J (2005) 16S rRNA sequences and differences in bacteria isolated from the Muztag Ata glacier at increasing depths. Appl Environ Microbiol 71:4619-4627

Zhang DC, Wang HX, Liu HC, Dong XZ, Zhou PJ (2006) Flavobacterium glaciei sp. nov., a psychrophilic bacterium isolated from the China No. 1 glacier. Int J Syst Evol Microbiol 56:2921-2925

Zhu F, Wang S, Zhou P (2003) Flavobacterium xinjiangense sp. nov. and Flavobacterium omnivorum sp. nov., novel psychrophiles from China No 1 glacier. Int J Syst Evol Microbiol 53:853-857 
